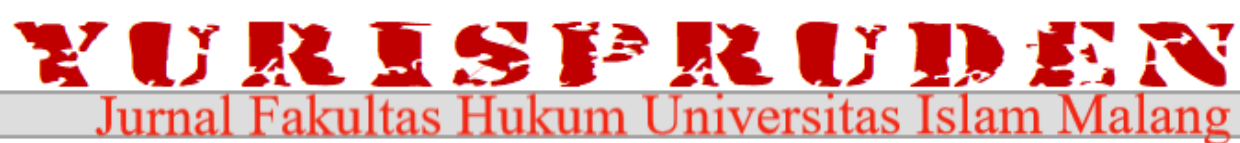 \\ Volume 5, Nomor 1, Januari 2022.
}

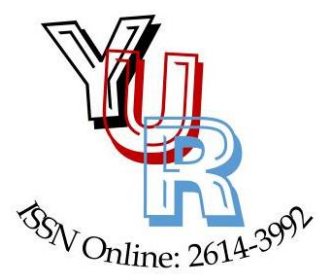

Editorial Office : Faculty of Law, Univeritas Islam Malang.

Jl. Mayjen Haryono No.193, Dinoyo, Kec. Lowokwaru, Malang, Provinsi Jawa Timur, 65144.

Phone $\quad$ :(0341) 551932 / 551822 / (0341) 552249

E-mail : yurispruden@unisma.ac.id

Website $\quad:$ http://riset.unisma.ac.id/index.php/yur/index

\section{Perlindungan Hukum Atas Kebocoran Data Dan Informasi Pribadi Pada Penumpang Transportasi Udara}

\section{Fitria Dewi Navisa, Angelina Septa Roekmanda Sari, Delfi Yumita Ramadhani}

Fakultas Hukum Universitas Islam Malang

Jl. MT. Haryono No.193 Malang, 65144, 0341-551932, Fax: 0341-552249

E-mail : navisa@unisma.ac.id

\section{Article}

Article History

Received: Nov 23, 2021;

Reviewed: Dec 22, 2021;

Accepted: Jan 05, 2022;

Published: Jan 20, 2022;

DOI:

10.33474/yur.v5i1.13935

\section{Abstract}

Air transportation service companies often fail to fulfill their consumer rights, such as being irresponsible for leaking passenger data. In connection with this case, there is a need for legal protection for consumers who feel that they have been harmed. This air transportation service provider has a huge responsibility to maintain the privacy of its passengers and consumers. So that by using a normative juridical research method, the author can take the subject matter raised, namely how is legal protection for air transportation services that are affected by data leaks carried out by irresponsible persons from airline companies. By using the theory of legal protection and legal certainty, the author can conclude that actions related to the spread of a personal matter are unlawful acts, whether intentional or not based on negligence, which can lead to liability such as compensation by the airline.

Keywords: Legal Protection, Data, Air Transport.

Abstrak
Perusahaan jasa tranportasi udara kerap melakukan kegagalan
dalam memenuhi hak konsumennya seperti tidak bertanggung
jawab atas kebocoran data penumpangnya. Sehubungan dengan
kasus tersebut, perlu adanya perlindungan hukum bagi konsumen
yang merasa dirinya dirugikan. Penyedia jasa angkutan udara ini
mempunyai tanggung jawab yang sangat besar untuk menjaga
data privasi penumpangnya maupun konsumen. Sehingga dengan
menggunakan metode penelitian yuridis normatif penulis dapat
mengambil pokok permasalahan yang diangkat yakni bagaimana
perlindungan hukum bagi penumpangan jasa transpotasi udara
yang terkena dampak kebocoran data yang dilakukan oleh oknum-
oknum tidak bertanggung jawab dari perusahaan maskapai
penerbangan. Dengan menggunakan teori perlindungan hukum
dan kepastian hukum penulis dapat menyimpulkan bahwa
perbuatan yang berhubungan tentang tersebarnya suatu hal yang
sifatnya pribadi adalah perbuatan melawan hukum baik disengaja


maupun tidak berdasarkan kelalaian dapat menimbulkan tanggung jawab seperti ganti kerugian oleh pihak maskapai.

Kata Kunci: Perlindungan Hukum, Data, Transportasi Udara.

\section{PENDAHULUAN}

Berkembang pesatnya teknologi khususnya dalam bidang transportasi membawa dampak positif bagi dunia penerbangan $^{1}$. Teknologi dalam bidang transportasi saat ini mempunyai dua sisi yang berdampak positif bahkan jika ada oknumoknum yang tidak bertanggung jawab hal tersebut dapat menimbulkan dampak negatif bagi salah satu pihak yang dirugikan.

Pesawat terbang adalah salah satu transportasi yang membantu suatu negara dalam mengembangkan perekonomian, memudahkan setiap masyarakatnya untuk menempuh perjalanan yang cukup panjang dan lama tetapi dengan transportasi udara dapat meminimalisir waktu jarak yang ditempuh sehingga sangat banyak masyarakat yang memanfaatkan transportasi tersebut. Kemajuan dalam dunia penerbangan meningkatkan berbagai aspek diantaranya aspek keamanan, aspek keselamatan dan masih banyak lagi.

Perlindungan hukum menurut Satjipto Rahardjo ialah bentuk pengayoman yang diberikan kepada Hak Asasi Manusia (HAM) dimana yang dirugikan terhadap salah satu pihak dan juga perlindungan tersebut diberikan untuk semua masyarakat sehingga mereka mendapat kenikmatan dalam segala macam bentuk dari hak yang diberikan oleh hukum.

Dengan perantara seorang aparat penegak hukum melakukan tindakan perlindungan hukum tersebut guna untuk memberikan bentuk kenyamanan baik dalam fisik maupun pikiran dan dari segala tindakan berbentuk ancaman yang berasal dari berbagai pihak. Perbuatan melawan hukum tersendiri diatur dalam Pasal 1365 Kitab Undang-Undang Hukum Perdata (KUHPer) yang mengatakan bahwa setiap orang atau pribadi yang melakukan sesuatu yang melanggar hukum dan menyebabkan kerugian bagi seseorang, diwajibkan untuk mengganti kerugian atas perbuatan melawan hukum yang telah dilakukannya. $^{2}$

Dapat ditarik unsur-unsur dalam pasal tersebut ialah terjadinya sebuah perbuatan melawan hukum, pasti ada kesalahan yang dapat merugikan seseorang dan atas perbuatan tersebut ada hubungan sebab dan akibatnya.

Unsur yang pertama ialah unsur melawan hukum yang berarti adanya tindakan

\footnotetext{
${ }^{1}$ Muhammad Taufik Hidayat, (Desember, 2016), Perlindungan Hukum Terhadap Pengguna Jasa Angkutan Udara Dalam Perspektif Peraturan Perundang-Undangan Tentang Penerbangan, Al'Adl, Volume 8, Nomor 3. hlm. 2.

${ }^{2}$ R. Subekti dan R. Tjitrosudibio, (2014), Kitab Undang-Undang Hukum Perdata, Jakarta: Balai Pustaka. hlm. 346.
} 
merugikan terhadap korban yang dilakukan oleh pelaku. Kedua adalah kesalahan baik itu disengaja atau kealpaan.

Sengaja yang dimaksud ialah suatu tindakan yang dilakukan oleh orang normal dengan sadar atau paham konsekuensi atas apa yang dilakukannya adalah perbuatan melanggar hukum. Sedangkan kealpaan disini yang dimaksud ialah seseorang mengabaikan sesuatu tetapi tidak dengan berhati-hati atau tidak teliti sehingga menimbulkan kerugian bagi pihak yang bersangkutan. ${ }^{3}$

Selanjutnya unsur ada sebab ada akibat dengan kata lain jika pelaku tidak melakukan hal yang merugikan, kerugian tersebut tidak akan ada atau terwujud. Ganti kerugian dibagi menjadi dua yaitu materiil dan imateriil. Ganti kerugian menurut KUHPer yaitu ganti rugi atas semua tindakan yang melanggar hukum terdapat pada Pasal 1365 KUHPer, ganti rugi atas tindakan yang orang lain perbuat Pasal 1367 KUHPer, ganti rugi atas penghinaan yang dilakukan orang lain Pasal 1372 KUHPer dan masih banyak lagi ganti kerugian yang telah disebutkan atau dicantumkan dalam KUHPer. ${ }^{4}$

Maka dari itu data privasi wajib dilindungi oleh hukum. Privasi tersendiri mempunyai makna suatu hak yang dimiliki oleh seseorang untuk menjaga kehidupan ataupun rahasia informasi yang hanya diketahui orang lebih sedikit orang.

Mengenai pengertian data pribadi dapat ditemui dalam Undang-Undang Nomor 23 Tahun 2006 Tentang Administrasi Kependudukan yang telah diubah menjadi Undang-Undang Nomor 24 Tahun 2013 Tentang Perubahan Atas Undang-Undang No 23 Tahun 2006 Tentang Administrasi Kependudukan. Pengertian data pribadi yaitu data yang wajib disimpan kebenarannya, dijaga kerahasiannya yang terdapat dalam Pasal 1 angka 22 Undang-Undang Nomor 24 Tahun 2013 Tentang Perubahan Atas Undang-Undang Nomor 23 Tahun 2006 Tentang Administrasi Kependudukan.

Dalam Pasal 28G ayat (1) UndangUndang Dasar Negara Republik Indonesia Tahun 1945 yang menyatakan setiap manusia berhak mendapatkan perlindungan diri maupun keluarga, harkat dan martabat, kehormatan serta harta yang dimiliki, berhak atas rasa aman dan nyaman dari berbagai ancaman untuk berbuat atau tidak berbuat sesuatu yang merupakan hak asasi. ${ }^{5}$

Pada dasarnya setiap manusia wajib memperoleh kepastian hukum atas kepemilikan dokumen, dokumen kependudukan, perlindungan atas data diri dan masih banyak lagi.

\footnotetext{
${ }^{3}$ Munir Fuady, (2002), Perbuatan Melawan Hukum: Pendekatan Kontemporer, Bandung: Citra Aditya Bakti. hlm. 73 .

${ }^{4}$ Ibid., hlm. 137.

${ }^{5}$ Pasal 28G ayat (1) Undang-Undang Dasar Negara Republik Indonesia Tahun 1945.
} 
Perlindungan privasi dalam sistem elektronik juga sama pentingnya dan dilindungi oleh hukum. Ketentuannya terdapat dalam Undang-Undang Nomor 11 Tahun 2008 Tentang Informasi dan Transaksi Elektronik yang telah diubah menjadi Undang-Undang Nomor 19 Tahun 2016 Tentang Perubahan Atas Undang-Undang Nomor 11 Tahun 2008 tentang Informasi dan Transaksi Elektronik.

Dalam media elektronik semua informasi yang menyangkut tentang data seseorang penggunaannya harus seizin orang yang bersangkutan. Pengertian hak pribadi ialah hak untuk mendapatkan kenyamanan kehidupan yang tentunya bebas dari segala ancaman kejahatan, hak untuk dapat berhubungan dengan orang lain tanpa adanya tindakan yang mecurigakan dan juga mencakup hak untuk dapat mengawasi akses informasi pribadi. ${ }^{6}$

Setiap masyarakat yang dilanggar haknya yang menimbulkan kerugian dapat melakukan gugatan terhadap pihak yang bersangkutan. Mengirimkan, menyebarluaskan, membuka data pribadi seseorang tanpa seizin yang bersangkutan adalah sebuah tindakan melawan hukum, karena tidak sembarang orang dapat mengakses data diri seseorang lalu menyebarkan ataupun membocorkannya dengan bebas tanpa seizin pemilik.

Berbagai upaya hukum tentunya mengatur dalam hal ini dan membrikan upaya dan jaminan atas rasa nyaman seseorang. Tentunya untuk kepentingan umum data diri wajib diserahkan dan seseorang yang bersangkutan dengan data tersebut memerlukan haknya.

Dalam Pasal 58 ayat (2) Undang-Undang Nomor 24 Tahun 2013 Tentang Administrasi Kependudukan menyebutkan kriteria data pribadi sebagai berikut: nomor Kartu Keluarga, Nomor Induk Kependudukan, Nama lengkap, Tempat Tangga Lahir, Jenis Kelamin, Agama, Status perkawinan, Nama Ibu, Nama Ayah, Jenis pekerjaan, Pendidikan Terakhir dan masih banyak lagi. Semua data yang bersifat pribadi sangat dapat dikaitkan dengan tindak kejahatan yang dilakukan oleh oknum-oknum yang tidak bertanggung jawab yang menyebabkan kerugian pemilik data tersebut.

Para oknum yang tidak bertanggung jawab dengan sengaja dapat menyalahgunakan data yang bukan miliknya tersebut guna kepentingan pribadi seperti disebarluaskan data diri seseorang yang mungkin dikenal di suatu negara tertentu, bisa

\footnotetext{
${ }^{6}$ Pasal 26 ayat (1) Undang-Undang Nomor 19 Tahun 2016 Tentang Perubahan Atas Undang-Undang Nomor 11 Tahun 2008 Tentang Informasi dan Transaksi Elektronik

${ }^{7}$ Rosalinda Elsina Latumahina, (Desember, 2014), Aspek Hukum Perlindungan Data Pribadi di Dunia Maya, Jurnal Aktualita, Volume 3, Nomor 2. hlm. 2.
} 
juga untuk transaksi online, digunakan untuk membuat identitas palsu dan lain sebagainya. ${ }^{8}$

Atas kejadian tersebut masyarakat menuntut adanya perlindungan hukum atas data dan diberikan jaminan yang terpercaya dalam semua kegiatan yang harus melibatkan adanya data pribadi sebagai jaminan dan lain sebagainya. Suatu data pribadi berhubungan dengan adanya teknologi transportasi modern seperti maskapai penerbangan dan perusahaan tersebut wajib menjaga kerahasiaan data konsumennya.

Dalam perkara perdata tidak ada batasan maksimal ataupun minimal untuk jumlah dan juga jenis kerugian yang dialami oleh pihak yang dirugikan untuk diminta, namun kerugian tersebut harus sesuai dengan dasar tuntutan yang diajukan (Pasal 1365 KUHPer). Perbuatan melawan hukum wajib untuk membayar ganti rugi atas perbuatanya. Dalam gugatan memang tidak disebutkan secara rinci tentang batas ganti kerugian tersebut, namun ketentuan umum terdapat dalam Pasal 1371 KUHPer yang menyatakan bahwa Juga untuk menuntut penggantian kerugian ini dinilai menurut kedudukan dan kemampuan kedua belah pihak dan menurut keadaan. ${ }^{9}$

Ada beberapa kasus kebocoran data oleh perusahaan maskapai yang merugikan korban tersendiri dengan menyebarkan data paspor yang kebetulan korban salah satu orang yang cukup dikenal di Indonesia. Kontroversi tersebut membuat jagat dunia maya heboh dan timbul kerugian bagi korban yang bersangkutan. Terkait kebocoran data penumpang, disinyalir $2 \%$ data penumpang yang berasal dari Indonesia, 66\% dari Malaysia dan juga India dengan jumlah 4\%. ${ }^{10}$

Berdasarkan pembahasan diatas, maka penulis tertarik mengkaji lebih dalam isu hukum yang berkaitan tentang bagaimana tanggung jawab pihak jasa penerbangan atas kerugian yang dialami oleh penumpang dan bagaimana upaya penyelesaian oleh konsumen atas kerugiannya. Sehingga mendapatkan kejelasan dalam persoalan "Perlindungan Hukum Atas Kebocoran Data Dan Informasi Pribadi Pada Penumpang Transportasi Udara"

Jenis penelitian dalam penelitian ini penulis menggunakan jenis penelitian yuridis normatif. Pendekatan penelitian yang penulis gunakan yaitu pendekatan peraturan perundang-undangan (statute approach) dan pendekatan konseptual (conseptual approach). Pendekatan perundang-undangan dilakukan dengan memahami semua

8 Nani Widya Sari, (Desember, 2018), Kejahatan Cyber dalam Perkembangan Teknologi Informasi Berbasis Komputer, Jurnal Surya Kencana Dua, Volume 5, Nomor 2. hlm. 1.

9 Fitria Dewi Navisa dan Rohmatun Nafisah, (Juni, 2020), Perlindungan Hukum Terhadap Keluarga Jenazah Yang Terkena Dampak Covid-19 Atas Penolakan Pemakaman, Yurispruden, Volume 3, Nomor 2. hlm. 146.

10 Redaksi, (2019), Duh, Jumlah Data Penumpang Anak Lion Air yang Bocor 7,8 Juta, diakses pada 5 November 2020 pukul 15.42 WIB, cnbcindonesia: https://www.cnbcindonesia.com/tech/20190927071442-37102593/duh-jumlah-data-penumpang-anak-lion-air-yang-bocor-78-juta. 
peraturan undang-undang yang bersangkutan dengan isu hukum yang penulis bahas. ${ }^{11}$

\section{PEMBAHASAN}

Dalam Pasal 1 poin ke 27 Peraturan Pemerintah Republik Indonesia Nomor 71 Tahun 2019 Tentang Penyelenggaraan Sistem dan Transaksi Elektronik, data pribadi ialah data setiap orang yang orang bersangkutan wajib untuk menyimpan, merawat, dan menjaga kebenarannya juga melindungi kerahasiaannya. $^{12}$

Adanya penegakan hukum dalam kehidupan setiap manusia untuk mengkoordinasi dan mengintergrasikan kepentingan yang biasanya bertentangan dengan satu sama lain. Dengan adanya hukum semua menjadi lebih terkoordinasi sehingga masalah-masalah atau benturan-benturan kepentingan dapat di minimalisir.

Pendapat mengenai pengertian hukum sendiri yang dinyatakan oleh R. Soeroso, bahwa hukum ialah suatu perkumpulan peraturan yang ditetapkan dan dibuat oleh seorang yang berwenang dengan tujuan agar mengatur kehidupan masyarakat tertata yang mempunyai ciri melarang dan sifatnya memaksa dengan konsekuensi jika salah satu masyarakatnya melakukan perbuatan yang telah dilarang oleh sebuah peraturan akan mendapatkan sanksi hukuman yang sepadan.
Pada Peraturan Pemerintah Republik Indonesia Nomor 80 Tahun 2017 Tentang Program Keamanan Penerbangan Nasional bertujuan untuk melindungi keselamatan, keteraturan dan efisiensi penerbangan di Indonesia melalui pemberian regulasi, standard dan prosedur serta perlindungan yang diperlukan bagi penumpang, awak pesawat udara, personel di darat dan masyarakat dari tindakan melawan hukum. ${ }^{13}$

Perlindungan sendiri mempunyai arti mengayomi sesuatu dari hal-hal yang berbahaya bisa berupa barang atau benda. Dapat juga diartikan sebagai pengayoman bagi seseorang yang lebih lemah. Upaya penegak hukum untuk menjamin kepastian hukum dan perlindungan bagi masyarakatnya agar hak asasi setiap manusia tidak dilanggar dan yang melanggar akan mendapatkan sanksi yang seberat-beratnya seperti yang diatur dalam peraturan undang-undang yang telah dibuat.

Perlindungan hukum adalah suatu yang diberikan kepada subjek hukum dalam bentu perangkat hukum guna memberikan masyarakat rasa aman yang bersifat mencegah maupun mengekang baik tulis ataupun lisan. Suatu perlindungan dapat dikatakan perlindungan hukum jika mengandung jaminan hukum, adanya sanksi yang berlaku,

11 Peter Mahmud Marzuki, (2017), Penelitian Hukum; Edisi Revisi, Cetakan ke-13, Jakarta: Kencana. hlm. 93.

12 Peraturan Pemerintah Republik Indonesia Nomor 82 Tahun 2012 Tentang Penyelenggaraan Sistem dan Transaksi Elektronik

13 Peraturan Pemerintah Republik Indonesia Nomor 80 Tahun 2017 Tentang Program Keamanan Penerbangan Nasional 
adanya pengayoman serta hak setiap masyarakat.

Bentuk perlindungan hukum memiliki sifat pencegahan dan hukuman. ${ }^{14}$ bentuk perlindungan hukum yang nyata ialah kejaksaan, kepolisian, pengadilan dan lembaga-lembaga lain yang dapa menyelesaikan suatu sengketa. Adapun hak dan kewajiban hukum, hak ialah sesuatu yang wajib kita dapatkan dan kewajiban ialah sesuatu hal yang wajib kita laksanakan. Pemenuhan hak dan kewajiban berhubungan dengan suatu kontrak.

Pada Pasal 1339 KUHPer. menyatakan bahwa suatu kontrak tidak hanya mengikat untuk semua hal yang tercantum dalam kontrak tersebut, tetapi juga semua hal yang menurut sifat kontrak diwajibkan oleh kebiasaan, kepatutan dan undang-undang. ${ }^{15}$

Sebagai negara yang sedang berkembang dan menjalin hubungan dengan negara satu dengan lain, Indonesia membutuhkan jasa transportasi untuk menghubungan dari pulau satu ke pulau lainnya. Jasa transportasi udara membuat kendala yang ada di Indonesia menjadi lebih mudah jika berkepentingan menuju pulau satu ke pulau lainnya dengan efisiensi waktu. $^{16}$

Dengan keuntungan efisiensi waktu, teknologi yang tinggi bahkan tidak mengenal batasan anatara negara satu dengan yang lain, serta memiliki keselamatan yang cukup dibandingkan transportasi lainnya. ${ }^{17}$ Juga terdapat berbagai resiko kerugian yang mungkin di dapat oleh konsumennya tidak hanya kecelakaan bahkan penyalahgunaan identitas diri yang berdampak pada konsekuensi hukum.

Untuk menentukan pertanggungjawaban atas terjadinya suatu masalah, perusahaan penerbangan wajib mengacu pada peraturan yang berlaku, sehingga konsumen dapat mengerti dan paham siapa pihak yang dapat bertanggungjawab atas kesalahannya, bentukbentuk pertanggungjawabannya, besar ganti kerugian dan masih banyak lagi.

Kegiatan penerbangan secara khusus telah diatur dalam Undang-Undang Nomor 1 Tahun 2009 Tentang Penerbangan. Penumpang dan juga konsumen pun mempunyai hak-hak yang dilindungi yang termuat dalam Undang-Undang Nomor 1 Tahun 1999 Tentang Perlindungan Konsumen.

Salah satu kasus seorang yang cukup dikenal di Indonesia, terkena dampak kerugian dikarenakan salah satu karyawan perusahaan jasa angkutan mengambil foto data diri korban dan disebarluaskan pada media sosial. Perbuatan tersebut sudah pasti

\footnotetext{
14 Rafael La Porta, (Oktober, 1999), Investor Protection and Cororate Governance, Journal of Financial Economic, Volume (__ $)$, Nomor 58. hlm. 9.

15 R Subekti dan R Tjitrosudibio, Op.cit., hlm. 342.

16 Soekardono, (1981), Hukum Dagang Indonesia Jilid 11, Jakarta: Rajawali Press. hlm. 4.

17 H.K. Martono, (1987), Hukum Udara, Angkutan Udara dan Hukum Angkasa, Bandung: Alumni. hlm. 102.
} 
perbuatan melawan hukum dan tertera dalam Pasal 1365 KUHPer bahwa setiap perbuatan melawan hukum dan membawa kerugian bagi mengganti kerugian tersebut.

Dalam arti luas perbuatan melawan hukum dapat diartikan sebagai suatu perbuatan yang bertentangan dengan kewajiban suatu peraturan hukum tetapi perbuatan tersebut juga melanggar kesusilaan dan kepantasan terhadap diri maupun benda milik orang lain yang ada di dalam masyarakat.

Unsur-unsur perbuatan melawan hukum sesuai dengan ketentuan Pasal 1365 KUHPer. adanya suatu perbuatan yang mengarah ke positif ataupun negatif. ${ }^{18}$ Kedua adalah suatau perbuatan tersebut harus melawan hukum seperti melawan ketentuan undang-undang yang berlaku, melanggar hak yang dimiliki orang lain, bertentangan dengan kewajiban hukum pelaku, melanggar kesusilaan dan perbuatan yang terlihat bertentangan dengan sikap baik dalam kehidupan bermasyarakat. ${ }^{19}$

Unsur ketiga adalah jika perbuatan pelaku menimbulkan kerugian bagi korban baik kerugian materiil maupun immateriil. Selanjutnya unsur adanya kesalahan yang dapat dimintai pertanggungjawaban jika perbuatan itu melanggar aturan hukum pihak lain, mewajibkan seseorang untuk

apabila sengaja ataupun lalai dan tidak ada pembenaran.

Unsur-unsur perbuatan melawan hukum menurut R. Suryatin meliputi perbuatan tersebut wajib melanggar ketentuan undangundang, perbuatan tersebut merugikan pihak lain antara sebab dan akibat wajib ada sebab musabab dan harus ada unsur kesalahan dari pelaku. $^{20}$

Jika timbul kerugian terhadap konsumen karena terjadinya kebocoran data akibat kelalaian pihak yang menyediakan jasa, tentu saja perilaku tersebut adalah perilaku melawan hukum. Sebab sudah tercantumnya peraturan pemerintah tentang penyelenggaraan sistem dan transaksi elektronik bahwa penyedia atau penyelenggara sistem elektronik wajib untuk menjamin tersedianya perjanjian keamanan informasi atau data pribadi terhadap layanan yang digunakan. ${ }^{21}$

Maka dari itu penyelenggara sistem elektronik wajib untuk menjaga kerahasiaan dan keutuhan dari data pribadi tersebut dan juga penggunaan data pribadi seseorang wajib dilakukan berdasar persetujuan pemilik data asli. Jika terjadi kegagalan dari pihak penyelenggara, wajib untuk memberikan

18 M.A. Moegni Djojodirdjo, (2010), Perbuatan Melawan Hukum, Jakarta: Pradnya Paramitha. hlm. 10. Ibid, hlm. 11 .

20 R. Suryanti, (2001), Hukum Perikatan, Jakarta: Pradnya Paramitha. hlm. 83.

21 Pasal 12 poin (b) Peraturan Pemerintah Republik Indonesia Nomor 82 Tahun 2012 tentang Penyelenggaraan Sistem dan Transaksi Elektronik. 
pemberitahuan secara tertulis kepada pihak yang dirugikan. ${ }^{22}$

Perilaku konsumen di Indonesia sangat dipengaruhi oleh tingkat pengetahuan dan kesadaran akan hak dan budaya hukumnya, mengingat perkembangan perlindungan konsumen itu sendiri baru mulai dirasakan sejak Undang-Undang Nomor 8 Tahun 1999 Tentang Perlindungan Konsumen disahkan dan diberlakukan. Budaya hukum merupakan faktor terpenting dalam meneliti perilaku konsumen dalam menyikapi perjanjian, khususnya perjanjian yang memuat klausula baku. $^{23}$

Menurut Prof. Hans W. Micklitz, dalam perlindungan konsumen secara garis besar dapat ditempuh dua model kebijakan. Pertama, kebijakan yang bersifat komplementer, yaitu kebijakan yang mewajibkan pelaku usaha memberikan informasi yang memadai kepada konsumen (hak atas informasi). Kedua, kebijakan kompensatoris, yaitu kebijakan yang berisikan perlindungan terhadap kepentingan ekonomi konsumen (hak atas keamanan dan kesehatan).

Cakupan perlindungan konsumen dapat dibedakan menjadi dua aspek yaitu:

1. Perlindungan terhadap konsumen akan kemungkinan barang yang diserahkan kepadanya tidak sesuai dengan apa yang sudah disepakati.

2. Perlindungan terhadap konsumen akan diberlakukannya syarat-syarat yang menurut konsumen tidak adil.

Konsumen tidak cukup dilindungi hanya berdasarkan kebijakan komplementer (memberikan informasi) saja, tetapi juga harus ditindaklanjuti dengan kebijakan kompensaoris guna meminimalisasi risiko yang ditanggung konsumen. Misalnya dengan mencegah produk berbahaya untuk tidak mencapai pasar sebelum lulus pengujian. ${ }^{24}$

Untuk itu hak konsumen sangat perlu untuk diketahui oleh konsumen itu sendiri, agar mereka dapat mengetahui apa saja Hak dan kewajiban yang di dapat dan mendapatkan kepastian hukum. Hak dan Kewajiban di Indonesia sudah diatur pada Pasal 4 Undang-Undang Nomor 8 Tahun 1999 Tentang Perlindungan Konsumen yaitu:

1. Hak Keamanan, kenyamanan, dan keselamatan dalam mengonsumsi barang dan/atau jasa.

2. Hak untuk memilih barang atau jasa dan juga mendapatkan barang atau jasa tersebut sesuai dengan nilai tukar dan kondisi serta jaminan yang dijanjikan.

3. Hak atas informasi yang benar, jelas dan jujur dan mengenai kondisi dan jaminan barang dan/atau jasa.

4. Hak untuk didengar pendapat atau keluhannya atas barang dan/atau jasa yang digunakannya.

22 Ibid.

23 David M.L. Tobing, (2019), Klausula Baku: Paradoks Dalam Penegakan Hukum Perlindungan Konsumen, Bandung: Gramedia Pustaka Utama. hlm. 95.

24 Shidarta, (2000), Hukum Perlindungan Konsumen Indonesia, Jakarta: Grasindo. hlm. 49. 
5. Hak untuk mendapatkan advokasi, perlindungan dan juga upaya penyelesaian sengketa perlindungan konsumen secara adil.

6. Hak untuk mendapatkan pembinaan dan pendidikan konsumen.

7. Hak untuk diperlakukann atau dilayani secara benar dan jujur secara tidak diskriminatif.

8. Hak untuk mendapatkan kompensasi, ganti rugi atau penggantian, apabila barang atau jasa yang diterima tidak sesuai dengan perjanjian awal atau tidak sebagaimana mestinya yang sudah dijanjikan.

9. Dan semua hak konsumen yang telah diatur dalam ketentuan perundangundangan lainnya. ${ }^{25}$

Jhon F. Kennedy melalui " $a$ Special Message for the Protection of Consumer Interest" mengemukakan hak konsumen yang harus dilindungi, meliputi:

1. Hak Memperoleh Keamanan (The Right To Safe Product)

Hak ini ditunjukkan terhadap perlindungan konsumen dari pemasaran barang dan/atau jasa yang membahayakan keselamatan konsumen. Pada posisi ini, peranan pemerintah guna menjamin keselamatan dan keamanan konsumen sangat diperlukan. Hal ini yang melandasi pentingnya pengaturan regulasi perlindungan konsumen untuk menjaga konsumen dari perilaku produsen yang dapat merugikan dan membahayakan konsumen.
2. Hak Memilih (The Right To Definite Choice In Selecting Product)

Merupakan hak prerogative konsumen dalam membeli atau tidak membeli suatu barang dan/atau jasa. Oleh karena itu, tanpa adanya hak untuk memperoleh informasi yang jujur, tingkat pendidikan yang memadahi, dan penghasilan yang memadahi, maka hak ini tidak akan banyak berari

3. Hak Mendapat Informasi (The Right To Be Informed About Product)

Merupakan mendapatkan informasi mempunyai arti yang sangat fundamental bagi konsumen. Setiap keterangan mengenai suatu barang dan/atau jasa yang akan dibeli atau digunakan haruslah diberikan informasi yang selengkap dan sejujur mungkin.

4. Hak Untuk Didengar (The Right To Be Heard Regarding Consumer Interest)

Hak ini untuk menjamin kepentingan konsumen harus diperhatikan dan tercermin dalam kebijakan yang diambil oleh pemerintah, termasuk didengar dalam pembuatan regulasi atau kebijakan yang memuat kepentingan konsumen di dalamnya. Selain itu, keluhan konsumen atas penggunaan suatu barang dan/atau jasa haruslah di dengar dan di wadahi dengan baik. ${ }^{26}$

Undang - Undang Nomor 8 Tahun 1999 Tentang Perlindungan Konsumen.

26 Zulham, (2017), Hukum Perlindungan Konsumen, Jakarta: Pernada Media. hlm. 48. 
Perserikatan Bangsa-Bangsa (PBB)

melalui resolusi Nomor A/RES/39/248

Tanggal 16 April 1985 Tentang Perlindungan

Konsumen (Guidelines for Consumer

Protection) merumuskan enam kepentingan

konsumen yang harus dilindungi, meliputi:

1) Perlindungan konsumen dari segala bahaya terhadap kesehatan dan juga keamanannya.

2) Promosi dan perlindungan kepentingan ekonomi social konsumen.

3) Tersediannya informasi yang memadai bagi konsumen atau memberikan kemampuan mereka melakukan pilihan yang tepat sesuai kehendak dan kebutuhan pribadi.

4) Pendidikan konsumen.

5) Tersediannya ganti rugi yang efektif.

6) Kebebasan untuk membentuk organisasi konsumen atau organisasi lainnya yang relevan dan memberikan kesempatan kepada organisasi tersebut untuk menyuarakan pendapatnya dalam pengambilan keputusan yang menyangkut kepentingan mereka.

Organisasi konsumen sedunia

(International Organization of Consumer

Union/IOCU) menambahkan empat hak dasar

konsumen yang harus dilindungi, yaitu:

1) Hak untuk memperoleh kebutuhan hidup

2) Hak untuk memperoleh ganti rugi.

3) Hak untuk memperoleh pendidikan konsumen

4) Hak untuk memperoleh lingkungan hidup yang bersih dan sehat. ${ }^{27}$

Lalu selain mendapatkan hak nya sebagai

Konsumen, Konsumen juga memiliki kewajiban untuk:

1) Membaca dan juga mengikuti petunjuk informasi juga prosedur yang sudah ada dalam pemakaian atau pemanfaatan barang atau jasa, demi keamanan dan keselamatan bersama.

2) Konsumen wajib berniat baik dalam melakukan transaksi pembelian barang atau jasa.

3) Membayar sesuai dengan nilai tukar yang disepakati.

4) Mengikuti upaya penyelesaian hukum sengketa perlindungan konsumen secara layak. $^{28}$

Prinsip-prinsip kedudukan konsumen dalam hubungan dengan pelaku usaha berdasarkan doktrin atau teori yang dikenal dalam perkembangan sejarah hukum perlindungan konsumen, antara lain :

1. Let The Buyer Beware (Caveat Emptor)

Doktrin let the buyer beware atau caveat emport merupakan dasar dari lahirnya sengketa di bidang transaksi konsumen. Asas ini berasumsi bahwa pelaku usaha dan konsumen adalah dua pihak yang sangat seimbang, sehingga konsumen tidak memerlukan perlindungan. Kelemahan prinsip ini konsumen tidak mendapat informasi yang memadai untuk menentukan pilihan terhadap barang dan/atau jasa yang dikonsumsinya. Sehingga apabila konsumen mengalami kerugian, maka pelaku usaha dapat berdalih bahwa kerugian tersebut akibat dari kelalaian konsumen sendiri.

2. The Due Care Theory

27 Ibid., hlm. 49.

28 Undang - Undang Nomor 8 Tahun 1999 Tentang Perlindungan Konsumen. 
Menyatakan bahwa pelaku usaha mempunyai kewajiban untuk berhati hati dalam memasarkan produk, baik barang maupun jasa. Selama peaku usaha berhati hati dengan produknya, maka ia tidak dapat dipersalahkan. Prinsip ini berlaku pembuktian siapa mendalilkan maka dialah yang membuktikan. Hal ini sesuai dengan jiwa pembuktian pada hukum privat di Indonesia yaitu pembuktian ada pada penggugat, sesuai dengan pasal 1865 KUHPer yang tegas menyatakan bahwa barangsiapa yang mendalilkan mempunyai suatu hak atau untuk meneguhkan haknya atau membantah hak orang lain, atau menunjuk pada suatu peristiwa, maka diwajibkan membuktikan adanya hak atau peristiwa tersebut. ${ }^{29}$

\section{The Privity of Contract}

Pelaku usaha mempunyai kewajiban untuk melindungi konsumen, tetapi hal itu baru dapat dilakukan jika diantara mereka telah terjalin suatu hubungan kontraktual. Pelaku usaha tidak dapat disalahkan diluar hal-hal yang diperjanjikan. Dengan demikian konsumen dapat mengguugat berdasarkan wanprestasi. Hal ini sesuai dengan ketentuan dalam pasal 1320 KUHPer yang menyatakan tentang ruang lingkup berlakunya perjanjian hanyalah antara pihak - pihak yang membuat perjanjian saja. ${ }^{30}$

Tujuan dari Undang-Undang Nomor 8 Tahun 1999 Tentang Perlindungan Konsumen ini bertujuan untuk melindungi kepentingan konsumen, satu sisi menjadi pecut bagi pelaku usaha untuk meningkatkan kualitasnya. Pada Pasal 3 Undang-Undang Nomor 8 Tahun 1999 Tentang Perlindungan Konsumen menjelaskan bahwa tujuan Perlindungan konsumen adalah:

1) Konsumen wajib meningkatkan kesadaran, kemampuan, dan juga kemandirian untuk melindungi dirinya.

2) Mengangkat harkat martabat konsumen dengan cara menghindarkannya dari akses yang negatif pemakaian barang atau jasa.

3) Meningkatkan pemberdayaan konsumen dalam memilih, menentukan, dan menuntut hak-hak nya sebagai seorang konsumen.

4) Menciptakan sistem perlindungan konsumen yang mengandung unsurunsur kepastian hukum dan juga informasi serta akses untuk mendapatkan informasi.

5) Menumbuhkan kesadaran pelaku usaha mengenai sangat pentingnya perlindungan konsumen sehingga tumbuh sikap yang jujur dan juga bertanggung jawab dalam berusaha.

6) Meningkatkan kualitas pada barang dan juga jasa yang dapat menjamin kelangsungan usaha dalam memproduksi barang dan jasa, kesehatan, keamanan, kenyamanan dan juga keselamatan seorang konsumen. ${ }^{31}$

29 R. Subekti dan R. Tjitrosudibio, Op.cit., hlm. 475.

30 Abdul Atsar dan Rani Apriani, (2019), Hukum Perlindungan Konsumen, Yogyakarta: Budi Utama. hlm. 45.

31 Undang - Undang Nomor 8 Tahun 1999 Tentang Perlindungan Konsumen. 
Pengertian pelaku usaha ${ }^{32}$

Pelaku usaha ialah perseorangan atau badan yang melakukan perjanjian dalam kegiatan usaha bersama konsumen. Berikut yang termasuk dalam pelaku usaha:

1) Korporasi

2) Perusahaan

3) Koperasi

4) BUMN

5) Pedagang

6) Impoter

7) Distributor, dan lain - lain. ${ }^{33}$

Hak dan kewajiban pelaku usaha berdasarkan Pasal 6 Undang-Undang Nomor

8 Tahun 1999 Tentang Perlindungan

Konsumen, adalah sebagai berikut:

1) Hak untuk menerima pembayaran yang sesuai dengan kesepakatan mengenai kondisi dan nilai tukar barang dan/atau jasa yang diperdagangkan.

2) Hak untuk mendapatkan perlindungan hukum dari tindakan konsumen yang beritikad tidak baik.

3) Hak untuk melakukan pembelaan diri sepatutnya di dalam penyelesaian hukum sengketa konsumen.

4) Hak untuk merehabilitasi nama baik apabila terbukti secara hukum bahwa kerugian konsumen tidak diakibatkan oleh barang/jasa yang diperdagangkan.

5) Hak - hak yang diatur dalam ketentuan peraturan perundang-undangan lainnya. $^{34}$

Kewajiban pelaku usaha berdasarkan

Pasal 7 Undang-Undang Nomor 8 Tahun

1999 Tentang Perlindungan Konsumen, adalah sebagai berikut:
1) Beritikad baik dalam melakukan kegiatan usahanya.

2) Memberikan informasi yang benar, jelas, dan jujur mengenai kondisi dan jaminan barang/jasa serta memberi penjelasan penggunaan, perbaikan, dan pemeliharaan.

3) Memperlakukan atau melayani konsumen secara benar dan jujur serta tidak diskriminatif.

4) Menjamin mutu barang/jasa yang diproduksi dan/atau diperdagangkan berdasarkaan ketentuan standar mutu barang dan/atau jasa yang berlaku.

5) Memberi esempatan kepada konsumen untuk menguji dan/atau mencoba barang/jasa tertentu serta memberi jaminan dan/atau garansi atas barang yang dibuat dan/atau yang diperdagangkan.

6) Memberikan kompensasi, ganti rugi, dan/atau penggantian atas kerugian akibat penggunaan, pemakaian dan pemanfaatan barang dan/atau jasa yang diperdagangkan.

7) Memberi kompensasi, ganti rugi, dan/atau penggantian apabila brang dan/atau jasa yang diterima atau dimanfaatkan tidak sesuai dengan perjanjian. ${ }^{35}$

Segala bentuk pelanggaran yang dilakukan oleh pelaku usaha mau tidak mau berimplikasi pada adanya hak konsumen untuk meminta pertanggungjawaban dari pelaku usaha yang telah merugikannya. Product liability adalah suatu tanggung jawab secara hukum dari orang/badan yang menghasilkan produk yang bergerak dalam suatu proses untuk menghasilkan suatu produk atau mendistribusikan produknya. ${ }^{36}$

32 Shidarta, (2006), Hukum Perlindungan Konsumen Indonesia, Jakarta: Grasindo. hlm. 61.

Rosmawati, (2018), Pokok-Pokok Hukum Perlindungan Konsumen, Jakarta: Prenada Median Group. hlm. 64.

34 Undang-Undang Nomor 8 Tahun 1999 Tentang Perlindungan Konsumen.

35 Ibid.

36 Happy Susanto, (2008), Hak-Hak Konsumen Jika Dirugikan, Jakarta: Transmedia Pustaka. hlm. 37. 
Berdasarkan Pasal 19 ayat (1) UndangUndang Nomor 8 Tahun 1999 Tentang Perlindungan Konsumen, pelaku usaha bertanggung jawab memberikan ganti rugi atas kerusakan, pencemaran, atau kerugian yang diderita konsumen akibat mengonsumsi barang/jasa yang dihasilkan atau diperdagangkan.

Sedangkan pada ayat (2), ganti rugi bisa berupa pengembalian uang, penggantian barang/jasa yang sesuai/setara dengan nilainya. Dan juga ganti rugi juga harus sesuai dengan ketentuan yang berlaku pada undangundang. ${ }^{37}$

Konsumen berada dalam posisi tidak seimbang dengan pelaku usaha dan cenderung menjadi pihak yang lemah. Ketidaktahuan konsumen dan rentannya konsumen menjadi sasaran dari tindakan pelaku usaha yang tidak memiliki itikad baik perlu diatur dalam peraturan perundang - undangan yang menurut larangan - larangan pelaku usaha dalam menjalankan kegiata usahanya.

Larangan bagi pelaku usaha bertujuan untuk mengupayakan barang dan/atau jasa yang beredar dimasyarakat merupakan produk yang layak edar asal - usul dan kualitas sesuai dengan informasi baik melalui label, etikat, iklan dan sebagainya. ${ }^{38}$ Ketentuan yang belaku pada Pelaku usaha diatur pada undangundang :
1. Pelaku usaha dilarang memproduksi dan/atau memperdagangkan barang dan/atau jasa yang :

a. Tidak memenuhi atau tidak sesuai dengan standar yang dipersyaratkan dan ketentuan peraturan perundangundangan;

b. Tidak sesuai dengan berat bersih, isi bersih atau netto, dan jumlah dalam hitungan sebagaimana yang dinyatakan dalam label atau etiket barang tersebut;

c. Tidak sesuai dengan ukuran, takaran, tiimbangan dan jumlah dalam hitungan menurut ukuran yang sebenarnya;

d. Tidak sesuai dengan kondisi, jaminan, keistimewaan atau kemanjuran sebagaimana dinyatakan dalam label, etiket atau keterangan barang dan/atau jasa tersebut;

e. Tidak sesuai dengan mutu, tingkatan, komposisi, proses pengolahan, gaya, mode, atau penggunaan tertentu sebagaimana dinyatakan dalam label atau keterangan barang dan/atau jasa tersebut;

f. Tidak sesuai dengan dengan janji yang dinyatakan dalam label, etiket, keterangan, iklan atau promosi penjualan barang dan/atau jasa tersebut;

g. Tidak mencantumkan tanggal kadaluarsa atau jangka waktu penggunaan/pemanfaatan yang paling baik atas barang tertentu;

h. Tidak mengikuti ketentuan berproduksi secara halal, sebagaimana pernyataan "halal" yang dicantumkan dalam label;

i. Tidak memasang label atau membuat penjelasan barang yang memuat nama barang, ukuran, berat/isi bersih atau netto, komposisi, aturan pakai, tanggal pembuatan, akibat sampingan, nama dan alamat pelaku usaha serta keterangan lain untuk penggunaan

37 Undang - Undang Nomor 8 Tahun 1999 Tentang Perlindungan Konsumen.

38 Husni Syawali dan Neni Sri, (2000), Hukum Perlindungan Konsumen, Bandung: Mandar Maju. hlm. 18. 
yang menurut ketentuan harus dipasang/ dibuat;

j. Tidak mencantumkan informasi dan/atau petnjuk penggunaan barang dalam bahasa Indonesia sesuai dengan ketentuan perundang - undangan yang berlaku.

2. Pelaku usaha dilarang memperdagangkan barang yang rusak, cacat atau bekas, tercemar tanpa memberikan informasi secara lengkap dan benar atas barang dimaksud.

3. Pelaku usaha dilarang memperdagangkan sediaan farmasi dan pangan yang rusak, cacat atau bekas dan tercemar, dengan atau tanpa memberikan infrmasi secara lengkap dan benar.

4. Pelaku usaha yang melakukan pelanggaran pada ayat (1) dan ayat (2) dilarang memperdagangkan barang dan/atau jasa tersebut serta wajib menariknya dari peredaran. ${ }^{39}$

Informasi atau keterangan suatu produk menjadi hal yang penting bagi konsumen, dan pelaku usaha harus memberikan informasi yang jelas. Sehingga pelaku usaha dapat di percaya dan bila melakukan pelanggaran dapat dipertanggung jawabkan.

\section{KESIMPULAN}

Tanggung jawab perusahaan yang mengakibatkan kerugian pada konsumen yaitu memberikan Ganti rugi sesuai dengan ketentuan pasal 1365 KUHPer. Ganti rugi ini sesuai ketentuan pada Pasal 7 UndangUndang Nomor 8 Tahun 1999 Tentang Perlindungan Konsumen dimana pelaku usaha berkewajiban memberikan kompensasi, ganti rugi, dan/atau jasa yang diperdagangkan. Pada Pasal 19 ayat (2) dijelaskan lebih lanjut tentang pengembalian barang dang penggantian barang dan/atau jasa yang sejenis atau setara nilainya.

Upaya penyelesaian bagi konsumen atas kerugian yang telah menimpanya, melalui 2 jalur yaitu non litigasi dan litigasi. Jika diluar pengadilan didasarkan pada ketentuan pasal 47 Undang-Undang Nomor 8 Tahun 1999 Tentang Perlindungan Konsumen. Dapat juga dilakukan secara litigasi dilakukan gugatan perbuatan melawan hukum ke pengadilan negeri berdasarkan undang - undang yang sudah di jelaskan yaitu Pasal 1365 KUHPer, dan Pasal 26 ayat (2) Tentang Informasi dan Transaksi Elektronik.

\section{DAFTAR PUSTAKA}

\section{Jurnal}

Fitria Dewi Navisa dan Rohmatun Nafisah, (Juni, 2020), Perlindungan Hukum Terhadap Keluarga Jenazah Yang Terkena Dampak Covid-19 Atas Penolakan Pemakaman, Yurispruden, Volume 3, Nomor 2.

Muhammad Taufik Hidayat, (Desember, 2016), Perlindungan Hukum Terhadap Pengguna Jasa Angkutan Udara Dalam Perspektif Peraturan PerundangUndangan Tentang Penerbangan, Al'Adl, Volume 8, Nomor 3.

Nani Widya Sari, (Desember, 2018), Kejahatan Cyber dalam Perkembangan Teknologi Informasi Berbasis Komputer, Jurnal Surya Kencana Dua, Volume 5, Nomor 2.

Rafael La Porta, (Oktober, 1999), Investor Protection and Cororate Governance, Journal of Financial Economic, Volume (__ $)$, Nomor 58.

\footnotetext{
${ }^{39}$ Pasal 8 Undang - Undang Nomor 8 Tahun 1999 Tentang Perlindungan Konsumen.
} 
Rosalinda Elsina Latumahina, (Desember, 2014), Aspek Hukum Perlindungan Data Pribadi di Dunia Maya, Jurnal Aktualita, Volume 3, Nomor 2.

\section{Internet}

Redaksi, (2019), Duh, Jumlah Data Penumpang Anak Lion Air yang Bocor 7,8 Juta, diakses pada 5 November 2020 pukul 15.42 WIB, cnbcindonesia: https://www.cnbcindonesia.com/tech/2 0190927071442-37-102593/duhjumlah-data-penumpang-anak-lion-airyang-bocor-78-juta.

\section{Buku}

Abdul Atsar dan Rani Apriani, (2019), Hukum Perlindungan Konsumen, Yogyakarta: Budi Utama.

David M.L. Tobing, (2019), Klausula Baku: Paradoks Dalam Penegakan Hukum Perlindungan Konsumen, Bandung: Gramedia Pustaka Utama.

H.K. Martono, (1987), Hukum Udara, Angkutan Udara dan Hukum Angkasa, Bandung: Alumni.

Happy Susanto, (2008), Hak - Hak Konsumen Jika Dirugikan, Jakarta: Transmedia Pustaka.

Husni Syawali dan Neni Sri, (2000), Hukum Perlindungan Konsumen, Bandung: Mandar Maju.
M.A. Moegni Djojodirdjo, (2010), Perbuatan Melawan Hukum, Jakarta: Pradnya Paramitha.

Munir Fuady, (2002), Perbuatan Melawan Hukum: Pendekatan Kontemporer, Bandung: Citra Aditya Bakti.

Peter Mahmud Marzuki, (2017), Penelitian Hukum; Edisi Revisi, Cetakan ke-13, Jakarta: Kencana.

R. Subekti dan R. Tjitrosudibio, (2014), Kitab Undang-Undang Hukum Perdata, Jakarta: Balai Pustaka.

R. Suryanti, (2001), Hukum Perikatan, Jakarta: Pradnya Paramitha.

Rosmawati, (2018), Pokok-Pokok Hukum Perlindungan Konsumen, Jakarta: Prenada Median Group.

Shidarta, (2000), Hukum Perlindungan Konsumen Indonesia, Jakarta: Grasindo.
_. (2006), Hukum Perlindungan Konsumen Indonesia, Jakarta: Grasindo.

Soekardono, (1981), Hukum Dagang Indonesia Jilid 11, Jakarta: Rajawali Press.

Zulham, (2017), Hukum Perlindungan Konsumen, Jakarta: Pernada Media. 